DEPARTMENT OF THE INTERIOR

U.S. GEOLOGICAL SURVEY

\title{
Analytical results and sample locality maps of rock samples from the eastern \\ Goodnews Bay quadrangle, southwest Alaska
}

By
J.E. Gray, B.M. Adrian, P.L. Hageman, and J.E. Kilburn

Open-File Report 92-8-A Paper version

92-8-B Diskette version

This report is preliminary and has not been reviewed for conformity with U.S. Geological Survey editorial standards and stratigraphic nomenclature. Any use of trade names is for descriptive purposes only and does not imply endorsement by the USGS.

U.S. Geological Survey, DFC, Box 25046, MS 973, Denver, C0, 80225 
CONTENTS

Page

STUDIES RELATED TO AMRAP.............................

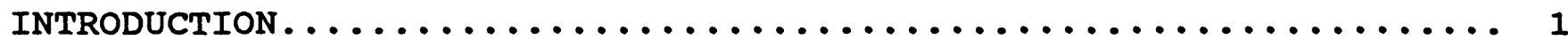

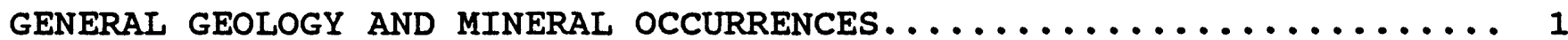

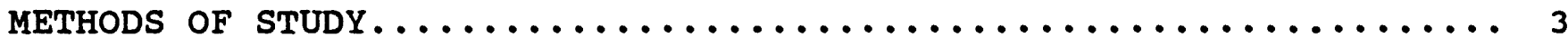

Sample collection................................ 3

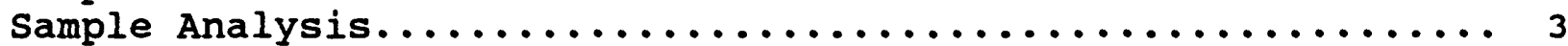

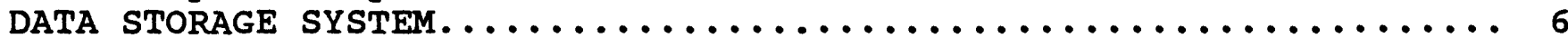

DESCRIPTION OF THE DATA TABLE......................... 6

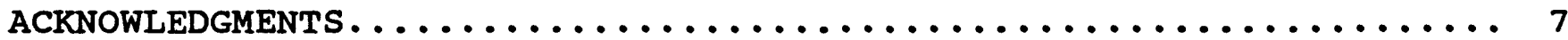

REFERENCES CITED................................... 7

\section{ILLUSTRATIONS}

Figure 1. Location of the Goodnews Bay quadrangle............ 2 Figure 2a. Localities of rock samples from the Goodnews Bay quadrangle......................... 4

Figure $2 \mathrm{~b}$. Localities of rock samples from the

Goodnews Bay quadrangle....................... 5

\section{TABLES}

Table 1. Iimits of determination for spectrographic analysis of

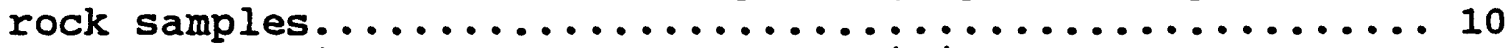

Table 2. Other analytical methods used and limits

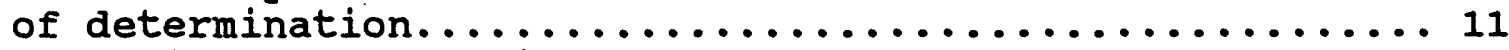

Table 3. Geologic and geochemical data for rock samples from the eastern portion of the Goodnews Bay quadrangle, Alaska... 12 


\section{STUDIES RELATED TO AMRAP}

The U.S. Geological Survey is required by the Alaska National Interests Lands Conservation Act (Public Law 96-487, 1980) to survey certain Federal lands to determine their mineral potential. Results from the Alaska Mineral Resource Assessment Program (AMRAP) must be made available to the public and submitted to the President and Congress. This report is one of a series of publications that presents geochemical results collected during the mineral assessment study of the Goodnews Bay quadrangle, Alaska (fig. 1). Geochemical data for rock samples collected from selected areas within the eastern portion of the Goodnews Bay quadrangle are presented here. The data in this report are also available on computer diskette in Gray and others (1992).

\section{INTRODUCTION}

Between 1975 and 1977, the U.S. Geological Survey conducted a reconnaissance geochemical survey of the Goodnews Bay, Hagemeister Island, and Nushagak Bay quadrangles as part of the mineral resource assessment of the region. Sample media collected included stream sediments, nonmagnetic heavy-mineral concentrates derived from stream sediments, and organic materials. A description of the sampling methods and analytical procedures used during the reconnaissance survey, along with a tabulation of the geochemical data and a site locality map for the samples are given in Cieutat and others (1988). Using the geochemical data of Cieutat and others (1988), Kilburn and Jones (1992) and Jones and Kilburn (1992) delineated a number of geochemically anomalous areas considered favorable for the presence of metallic mineral resources. Geochemical anomalies identified in the eastern part of the Goodnews Bay quadrangle were the subject of a follow-up field investigation in the summer of 1990. During this follow-up study, altered and mineralized rocks were collected in most areas identified by the geochemical reconnaissance study as anomalous. In addition, rock samples were collected from two poorly studied mineral occurrences, a sphalerite-rich vein along the Togiak River (Hoare and Cobb, 1977), and a Hg-rich occurrence near the ongivinuck River (Coonrad and others, 1978). This report presents only the locations, brief descriptions, and the analytical data for rock samples collected during the 1990 follow-up study. The data listed in this report were interpreted by Kilburn and others (1992). The mineral assessment report for the Goodnews Bay study appears in Kilburn and others (in press).

\section{GENERAL GEOLOGY AND MINERAL OCCURRENCES}

The eastern Goodnews Bay quadrangle is underlain primarily by northeast-striking rocks of the Togiak tectonostratigraphic terrane (Jones and others, 1987; Box, 1985). This structurally complex terrane is characterized by a thick sequence of Jurassic graywacke and Jurassic and Early Cretaceous interbedded breccia, tuff, basalt, tuffaceous siltstone, and chert. The volcanic, volcaniclastic, and sedimentary rocks of the Togiak terrane are intruded locally by felsic 


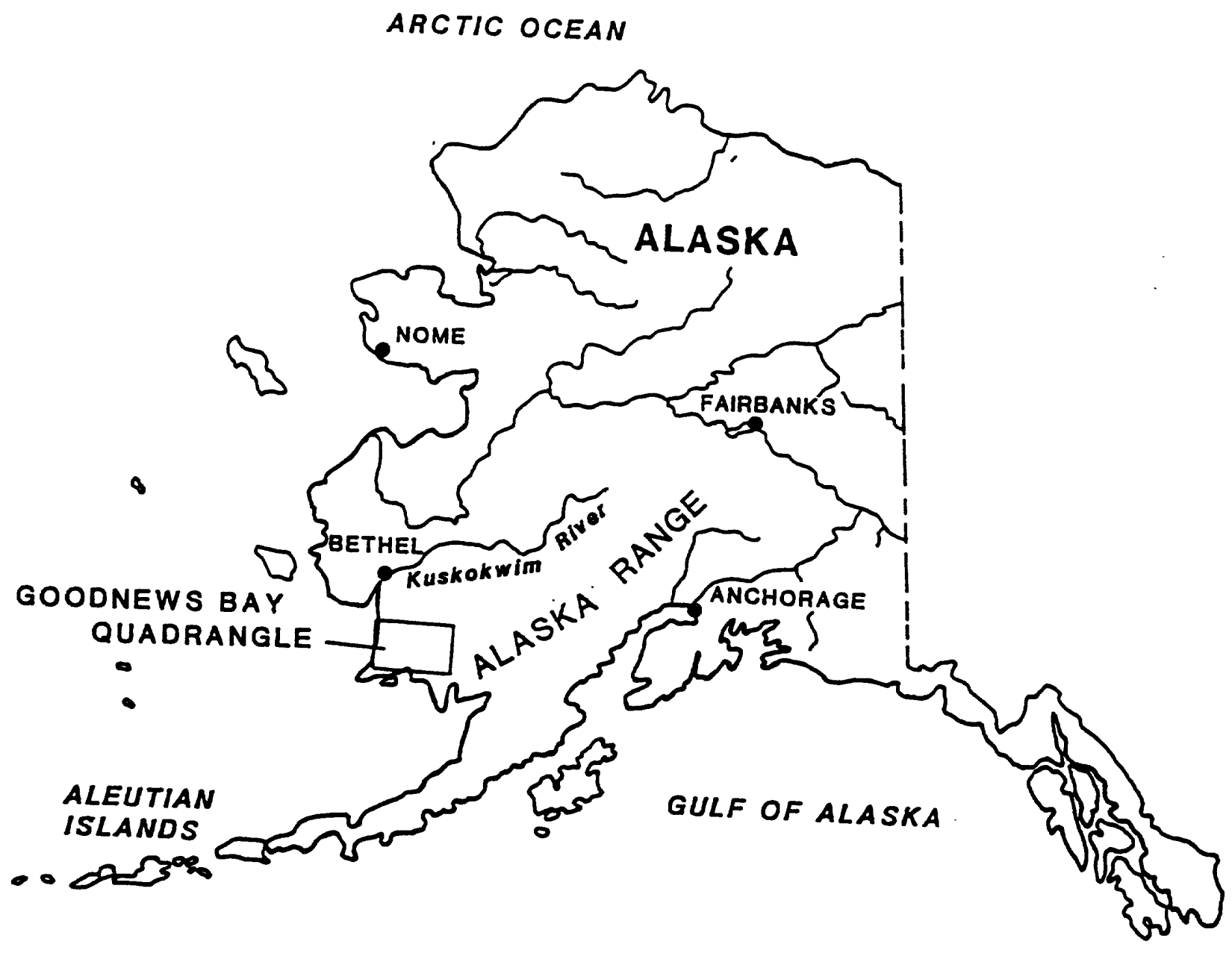

Figure 1. Location of the Goodnews Bay quadrangle, Alaska. 
stocks of Late Cretaceous to early Tertiary age. Major structural features, some of which appear to delineate terrane boundaries, trend northeast to north-northeast (Hoare and Coonrad, 1978). The most detailed account of the geology and a correlation of rock units is given in Hoare and Coonrad (1978).

The Bristol Bay mining region, which is regarded as one mining district, encompasses the eastern part of the Goodnews Bay quadrangle (Cobb, 1973). Only a few small $\mathrm{Hg}-, \mathrm{Cu}-$, and $\mathrm{Zn}$-bearing quartz veins and reports of scattered Au placers were documented in the eastern Goodnews Bay region (Eberlein and others, 1977) prior to the 1990 follow-up study. Quartz veins include a sphalerite-bearing occurrence with minor amounts of chalcopyrite in altered pillow lava just south of the Kashaiak Mountains along the Togiak River (Berg and Cobb, 1967), the cinnabar-stibnite-realgar-orpiment-bearing Kagati lake prospect hosted in a Late Cretaceous granitic stock located several $\mathrm{km}$ east of Kagati Lake near Mount Oratia (Sainsbury and Mackevett, 1965), and small copper-rich veins hosted in a Late cretaceous to Tertiary granitic stock in the Pistuk Peak-Togiak Lake region (Eakins, 1968; Hoare and Cobb, 1977). Gold-bearing placers were reported at several sites along Trail and Rainy Creeks, and minor placer gold was reported in creeks that drain the ridge southwest of Sunshine Valley and streams entering Elva Lake (Hoare and Cobb, 1977). Newly discovered base- and precious-metal-bearing veins in the eastern Goodnews Bay quadrangle are described in Kilburn and others (1992).

\section{METHODS OF STUDY}

\section{Sample collection}

Geochemical sampling for this follow-up study consisted of rock samples collected from outcrop, ridge float, or talus slopes. outcrop rock samples were collected as composite chip samples that were as representative as possible of the exposed rocks. Most samples were collected from altered or mineralized rocks. This report contains analytical data for approximately 100 rock samples that were collected from areas in the eastern portion of the Goodnews Bay quadrangle (figs. $2 \mathrm{a}$ and $2 \mathrm{~b}$ ).

\section{Sample Analysis}

Rock samples were crushed and pulverized to minus-100 mesh (150 $\mu \mathrm{m})$ using a disk mill with ceramic plates. The pulverized samples were analyzed for a variety of elements by different chemical methods. Samples were analyzed for 35 elements using a semiquantitative, direct-current arc emission spectrographic method (Grimes and Marranzino, 1968). Spectrographic results were determined by visually comparing spectra derived from the sample against spectra obtained from laboratory reference standards. Standard concentrations are geometrically spaced over any given order of magnitude of concentration such that values reported for each sample are reported in a geometric sequence $10,15,20,30,50,70,100$, etc. The elements determined by the spectrographic method and their limits of determination are listed in table 1 .

The samples were also analyzed for 10 elements by inductively coupled plasma-atomic emission spectrometry after a partial digestion of a 1-gram aliquot and organic solvent extraction (Motooka, 1988). 


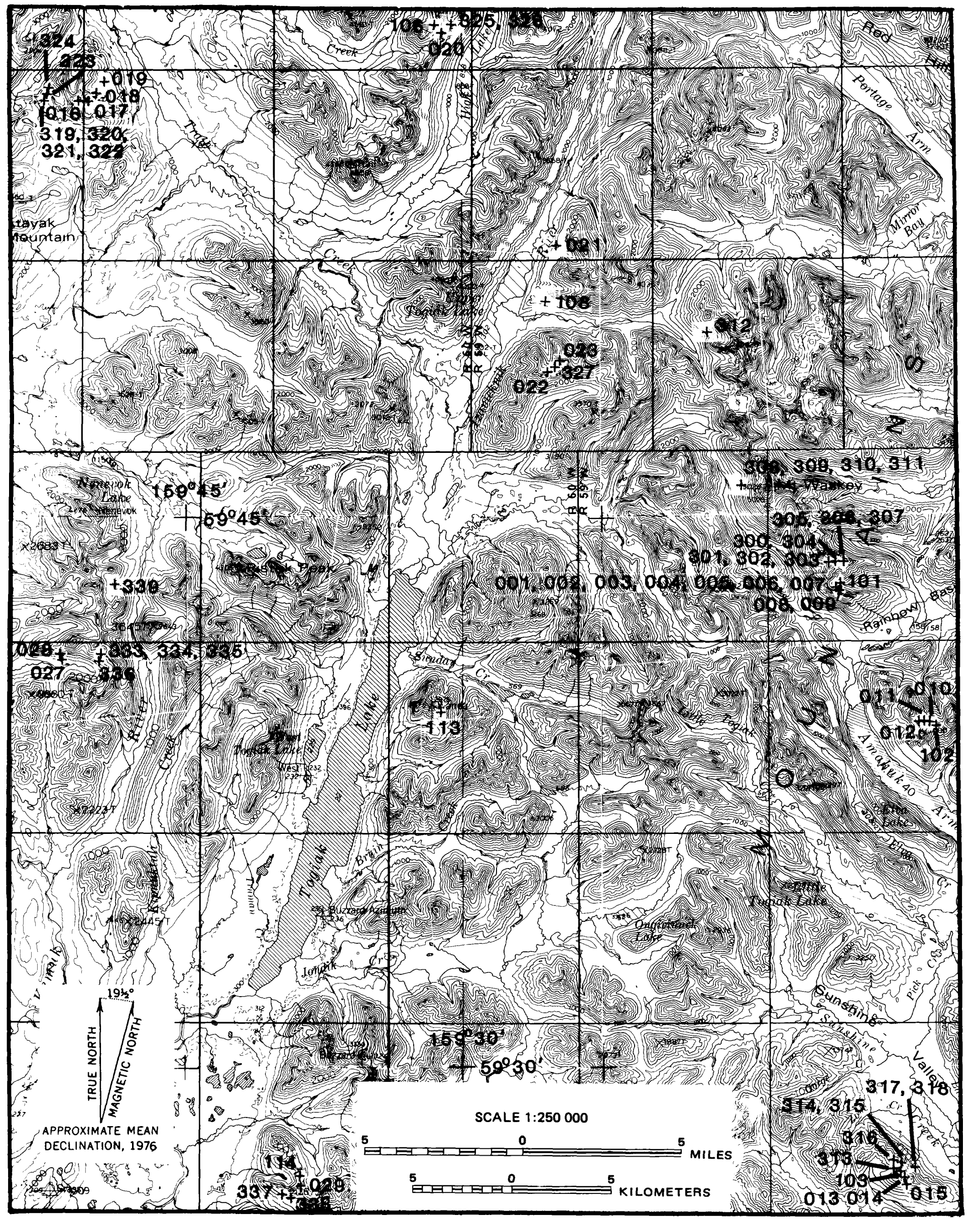

Figure 2a. Localities of rock samples from the Goodnews Bay quadrangle. 


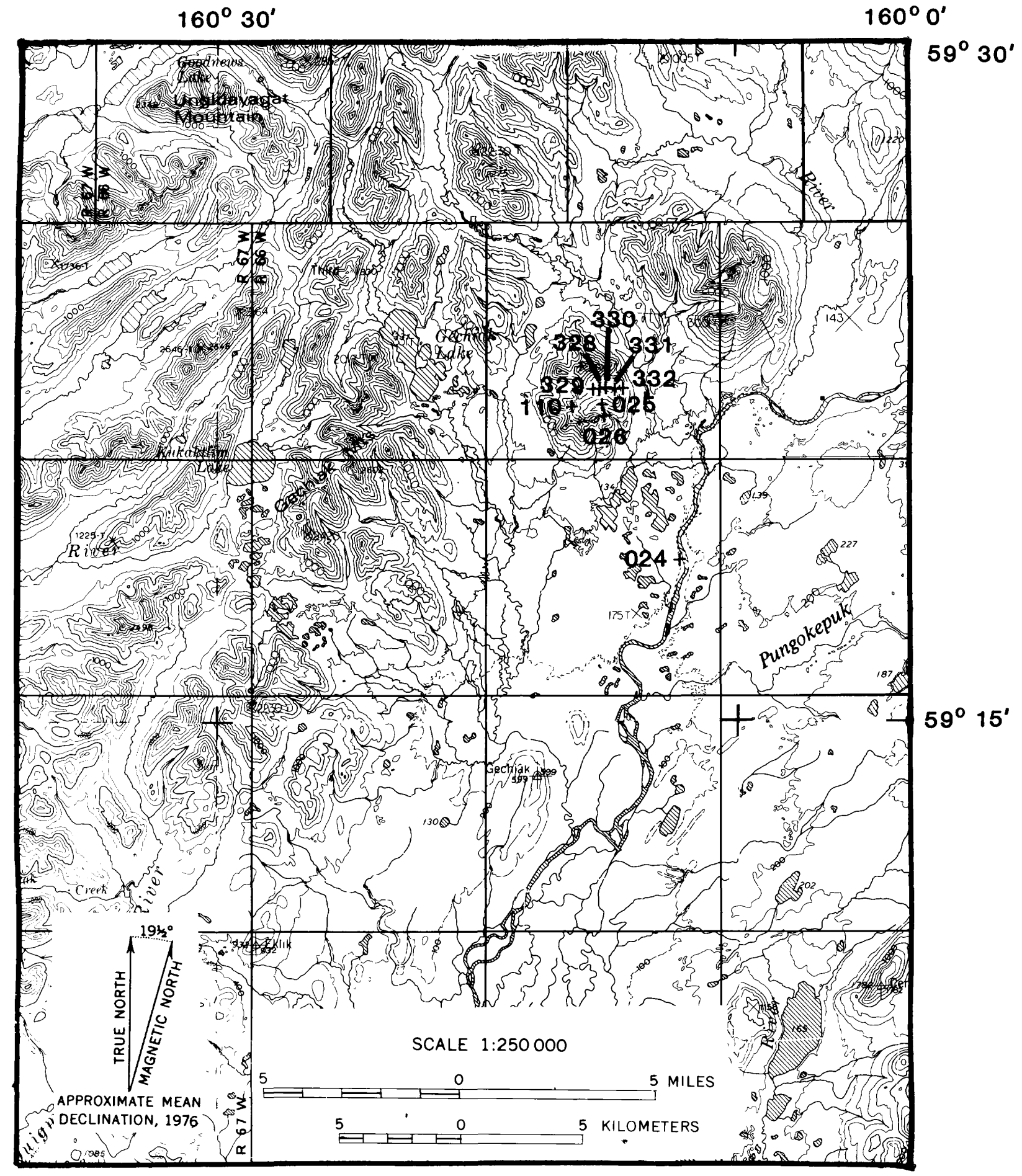

Figure 2b. Localities of rock samples from the Goodnews Bay quadrangle. 
Table 2 lists the elements analyzed by inductively coupled plasmaatomic emission spectrometry and limits of determination. In addition, gold was determined by graphite furnace atomic absorption spectrophotometry following a hydrobromic acid-bromine digestion of a 10-gram aliquot and an organic solvent extraction (O'Leary and Meier, 1986). Tungsten was determined by a visible spectrophotometric method by decomposing the sample with nitric, hydrofluoric, and hydrochloric acids (Welsch, 1983). Mercury was determined using a modified version of the cold-vapor atomic absorption spectrophotometry method of Kennedy and Crock (1987). Lower limits of determination for Au, W, and $\mathrm{Hg}$ by these methods are also listed in table 2 .

Discrepancies in analyses for certain elements duplicated by different analytical methods, such as values determined for Au, may be attributable to the particulate nature of minerals that contain Au, different sample aliquots used, and different extraction procedures. The atomic absorption spectrophotometry analysis of Au provides the most statistically representative results due to the larger sample aliquot analyzed. For example, a 10-gram sample aliquot is used for the atomic absorption analysis, whereas a 10-milligram sample aliquot is used in the spectrographic technique.

\section{DATA STORAGE SYSTEM}

Upon completion of the analytical work, the results were entered into a computer-based file as part of the USGS Rock Analysis storage System (RASS) database. This database contains both descriptive geological information and analytical data. Any of this information may be retrieved and converted to a binary form (STATPAC) for computerized analysis or publication (VanTrump and Miesch, 1976).

The data in this report are also available on a 5.25 inch, 360-Kb magnetic diskette in Gray and others (1992). Access to this information requires an IBM compatible computer using MS DOS and a 5.25 inch drive capable of handling $360-\mathrm{Kb}$ diskettes. The diskette report contains the analytical results for the rock samples in STATPAC file (.STP) format. An executable data conversion program STP2DAT.EXE (Grundy and Miesch, 1987) is also contained on the diskette that provides various format options into which the .STP file may be changed.

\section{DESCRIPTION OF DATA TABLE}

Table 3 contains summary geologic information and analytical results for the rock samples collected during this study. Locations are given in latitude and longitude in table 3 and these locations are plotted on figures $2 \mathrm{a}$ and $2 \mathrm{~b}$. Abbreviations in table 3 in the columns labeled "notes" and "ore and alteration minerals" are: ALT. = alteration; ARSENO = arsenopyrite; $\mathrm{BLCHED}=$ bleached; $\mathrm{CHALCO}=$ chalcopyrite; DISS = disseminated; HLY = highly; PLAG. = plagioclase; PORPH. = porphyrY; QTZ = quartz; and SILCFD = silicified.

The analytical method for each element shown in table 3 is abbreviated as a suffix in the column headings with the designations "S", "P", "AA", and "VS" indicating semiquantitative optical emission spectrography, inductively coupled plasma-atomic emission 
spectrometry, atomic absorption spectrophotometry, and visible spectrophotometry analyses, respectively. The letter " $N$ " in the data table indicates that an element was looked for but not observed at the concentration shown, while an "L" indicates that an element was observed but present in concentrations below the lower limit of determination shown. A "G" was entered in the table after the upper limit of determination if an element was observed but was present in concentrations above this value. Lower and upper limits of determination for the inductively coupled plasma-atomic emission spectrometry method listed in this table may be variable due to variable sample aliquot weight, dilution of an analytical aliquot, or instrumental interference correction. Values determined for the major elements, $\mathrm{Fe}, \mathrm{Mg}, \mathrm{Ca}, \mathrm{Na}, \mathrm{Ti}$, and $\mathrm{P}$ are given in weight percent; all other values are in parts per million (micrograms/gram).

\section{ACRNOWLEDGMENTS}

We would like to acknowledge R. Goldfarb and S. Box for their assistance with sample collection in the field. In addition, we thank D. Abrams, J. Kelley, and C. Motooka for sample preparation; J. Motooka and $\mathrm{B}$. Roushey for chemical analyses; and $\mathrm{K}$. Slaughter for assistance with report preparation and data reduction.

\section{REFERENCES CITED}

Berg, H.C., and Cobb, E.H., 1967, Metalliferous lode deposits of Alaska: U.S. Geological Survey Bulletin 1246, $254 \mathrm{p}$.

Box, S.E., 1985, Terrane analysis of the northern Bristol Bay region, southwestern Alaska, in Bartsch-Winkler, Susan, ed.: U.S. Geological Survey Circular 967, p. 32-37.

Cieutat, B.A., Goldfarb, R.J., and Speckman, W.S., 1988, Analytical results and sample locality map of stream sediment, heavy-mineral concentrate, and organic material samples from the Goodnews, Hagemeister Island, and Nushagak Bay quadrangles, southwest Alaska: U.S. Geological Survey Open-File Report 88-591, 187 p.

Cobb, E.H., 1973, Placer deposits of Alaska: U.S. Geological Survey Bulletin 1374, $213 \mathrm{p}$.

Coonrad, W.L., Hoare, J.M., Taufen, P.M., and Hessin, T.D., 1978, Geochemical analysis of rock samples in the Goodnews and Hagemeister Island quadrangles region, southwestern Alaska: U.S. Geological Survey Open-File Report 78-9-H, scale 1:250,000.

Eakins, G.R., 1968, A geochemical investigation of the Wood RiverTikchik Lakes area, southwestern Alaska: Alaska Division of Mines and Minerals Geochemical Report 17, $31 \mathrm{p}$. 
Eberlein, G.D., Chapman, R.M., Foster, H.L., and Gassaway, J.S., 1977, Table describing known metalliferous and selected nonmetalliferous mineral deposits in central Alaska: U.S. Geological Survey Open-File Map 77-168-D.

Grimes, D.J., and Marranzino, A.P., 1968, Direct-current arc and alternating current spark emission spectrographic field methods for the semiquantitative analysis of geologic materials: U.S. Geological Survey Circular 591, 6 p.

Gray, J.E., Adrian, B.M., Hageman, P.I., and Kilburn, J.E., 1992, Diskette version of analytical results of rock samples from the eastern Goodnews Bay quadrangle, southwest Alaska: U.S. Geological Survey Open-File Report 92-8-B, 1-1.2 MB diskette.

Grundy, W.R., and Miesch, A.T., 1987, Brief descriptions of STATPAC and related statistical programs for the IBM Personal Computer: U.S. Geological Survey Open-file Report 87-411-A; 34 p.

Hoare, J.M., and Cobb, E.H., 1977, Mineral occurrences (other than mineral fuels and construction materials) in the Bethel, Goodnews, and Russian Mission quadrangles, Alaska: U.S. Geological Survey Open-File Report 77-156, 98 p.

Hoare, J.M., and Coonrad, W.L., 1978, Geologic map of the Goodnews and Hagemeister Island quadrangles region, southwestern Alaska: U.S. Geological Survey Open-File Report 78-9-B, scale 1:250,000.

Jones, D.I., Silberling, N.I., Coney, P.J., and Plafker, George, 1987, Lithotectonic terrane map of Alaska (west of the 141st meridian): U.S. Geological Survey Miscellaneous Field studies Map MF-1874-A, scale $1: 250,000$.

Jones, J.L., and Kilburn, J.E., 1992, Geochemical map showing the distribution of selected elements in heavy-mineral concentrate samples from the Goodnews Bay, Hagemeister Island, and Nushagak Bay quadrangles, Alaska: U.S. Geological Survey Miscellaneous Field Studies Map MF-2186, 2 sheets, scale 1:250,000.

Kennedy, K.R., and Crock, J.G., 1987, Determination of mercury in geologic materials by continuous flow, cold-vapor, atomicabsorption spectrophotometry: Analytical Letters, v. 20, p. 899908 .

Kilburn, J.E., Box, S.E., Goldfarb, R.J., and Gray, J.E., 1992, Geochemically anomalous areas in the eastern Goodnews Bay $1^{\circ}$ by $3^{\circ}$ quadrangle, southwest Alaska, in Bradley, D.C., and Ford, A.B., eds., Geologic studies in Alaska by the U.S. Geological Survey, 1990: U.S. Geological Survey Bulletin 1999, p. 156-162. 
Kilburn, J.E., Goldfarb, R.J., Griscom, Andrew, and Box, S.E., in press, Map showing metallic mineral resource potential in the Goodnews Bay, Hagemeister Island, and Nushagak Bay $1^{\circ} \mathrm{X} 3^{\circ}$ quadrangles, Southwest Alaska: U.S. Geological Survey Miscellaneous Field Studies Map.

Kilburn, J.E., and Jones, J.I., 1992, Geochemical map showing the distribution of selected elements in stream sediments from the Goodnews Bay, Hagemeister Island, and Nushagak Bay quadrangles, Alaska: U.S. Geological Survey Miscellaneous Field Studies Map MF-2355, 2 sheets, scale 1:250,000.

Motooka, J.M., 1988, An exploration geochemical technique for the determination of preconcentrated organometallic halides by ICPAES: Applied Spectroscopy, v. 42, no. 7, p. 1293-1296.

O'Leary, R.M., and Meier, A.L., 1986, Analytical methods used in geochemical exploration, 1984: U.S. Geological Survey Circular $948,48 \mathrm{p}$.

Sainsbury, C.L., and Mackevett, E.M., Jr., 1965, Quicksilver deposits of southwestern Alaska: U.S. Geological Survey Bulletin 1187, 89 p.

VanTrump, George, Jr., and Miesch, A.T., 1976, The U.S. Geological Survey RASS-STATPAC system for management and statistical reduction of geochemical data: Computers and Geosciences, v. 3, p. 475-388.

Welsch, E.P., 1983, A rapid geochemical spectrophotometric determination of tungsten with dithiol: Talanta, v. 30, p. 876878 . 
Table 1. Limits of determination for the spectrographic analysis of rock samples, based on a 10-mg sample.

\begin{tabular}{lcc}
\hline Elements & Lower determination limit & Upper determination limit \\
& \multicolumn{2}{c}{ Percent } \\
\hline & & 20 \\
Iron (Fe) & 0.05 & 10 \\
Magnesium (Mg) & 0.02 & 20 \\
Calcium (Ca) & 0.05 & 5 \\
Sodium (Na) & 0.2 & 1 \\
Titanium (Ti) & 0.002 & 10 \\
Phosphorous (P) & 0.2 & \\
\end{tabular}

Parts per million

\begin{tabular}{|c|c|c|}
\hline Silver $(\mathrm{Ag})$ & 0.5 & 5,000 \\
\hline Arsenic (As) & 200 & 10,000 \\
\hline Gold (Au) & 10 & 500 \\
\hline Boron (B) & 10 & 2,000 \\
\hline Barium (Ba) & 20 & 5,000 \\
\hline Beryllium (Be) & 1 & 1,000 \\
\hline Bismuth (Bi) & 10 & 1,000 \\
\hline Cadmium (cd) & 20 & 500 \\
\hline cobalt (Co) & 10 & 2,000 \\
\hline Chromium (Cr) & 10 & 5,000 \\
\hline Copper (Cu) & 5 & 20,000 \\
\hline Gallium (Ga) & 5 & 100 \\
\hline Germanium (Ge) & 10 & 100 \\
\hline Lanthanum (La) & 50 & 1,000 \\
\hline Manganese (Mn) & 10 & 5,000 \\
\hline Molybdenum (Mo) & 5 & 2,000 \\
\hline Niobium ( $\mathrm{Nb})$ & 20 & 2,000 \\
\hline Nickel (Ni) & 5 & 5,000 \\
\hline Lead ( $\mathrm{Pb}$ ) & 10 & 20,000 \\
\hline Antimony (Sb) & 100 & 10,000 \\
\hline Scandium (Sc) & 5 & 100 \\
\hline $\operatorname{Tin}(\mathrm{Sn})$ & 10 & 1,000 \\
\hline strontium (Sr) & 100 & 5,000 \\
\hline Thorium (Th) & 100 & 2,000 \\
\hline Vanadium (V) & 10 & 10,000 \\
\hline Tungsten (W) & 20 & 10,000 \\
\hline Yttrium (Y) & 10 & 2,000 \\
\hline Zinc $(\mathrm{Zn})$ & 200 & 10,000 \\
\hline Zirconium ( $\mathrm{zr}$ ) & 10 & 1,000 \\
\hline
\end{tabular}


Table 2. Other analytical methods used and limits of determination*. [ICP-AES, Inductively Coupled Plasma-Atomic Emission Spectrometry; CVAAS, Cold-Vapor Atomic Absorption spectrophotometry; GFAAS, Graphite Furnace Atomic Absorption Spectrophotometry; VS, Visible spectrophotometry].

\begin{tabular}{llll}
\hline & $\begin{array}{c}\text { Analytical } \\
\text { Method }\end{array}$ & $\begin{array}{c}\text { Lower Iimit } \\
\text { (ppm) }\end{array}$ & $\begin{array}{c}\text { Upper Iimit } \\
\text { (ppm) }\end{array}$ \\
\hline Silver (Ag) & ICP-AES & 0.045 & 1,500 \\
Arsenic (As) & ICP-AES & 0.6 & 3,000 \\
Gold (Au) & ICP-AES & 0.15 & 2,400 \\
Bismuth (Bi) & ICP-AES & 0.6 & 1,500 \\
Cadmium (Cd) & ICP-AES & 0.03 & 500 \\
Copper (Cu) & ICP-AES & 0.03 & 1,200 \\
Molybdenum (Mo) & ICP-AES & 0.09 & 1,500 \\
Lead (Pb) (Sb) & ICP-AES & 0.6 & 12,000 \\
Antimony (Sb) & ICP-AES & 0.6 & 800 \\
Zinc (Zn) & ICP-AES & 0.03 & 500 \\
\hline & & & \\
Gold (Au) & GFAAS & 0.002 & \\
Mercury (Hg) & CVAAS & 0.02 & \\
Tungsten (W) & VS & 1 & \\
\hline
\end{tabular}

* NOTE: Lower and upper limits of determination for the ICP-AES method listed in this table are nominal, and in table 3 may be variable. The variability in limits of determination for an element is due to variable sample aliquot weight, dilution of an analytical aliquot, or instrumental interference correction. 


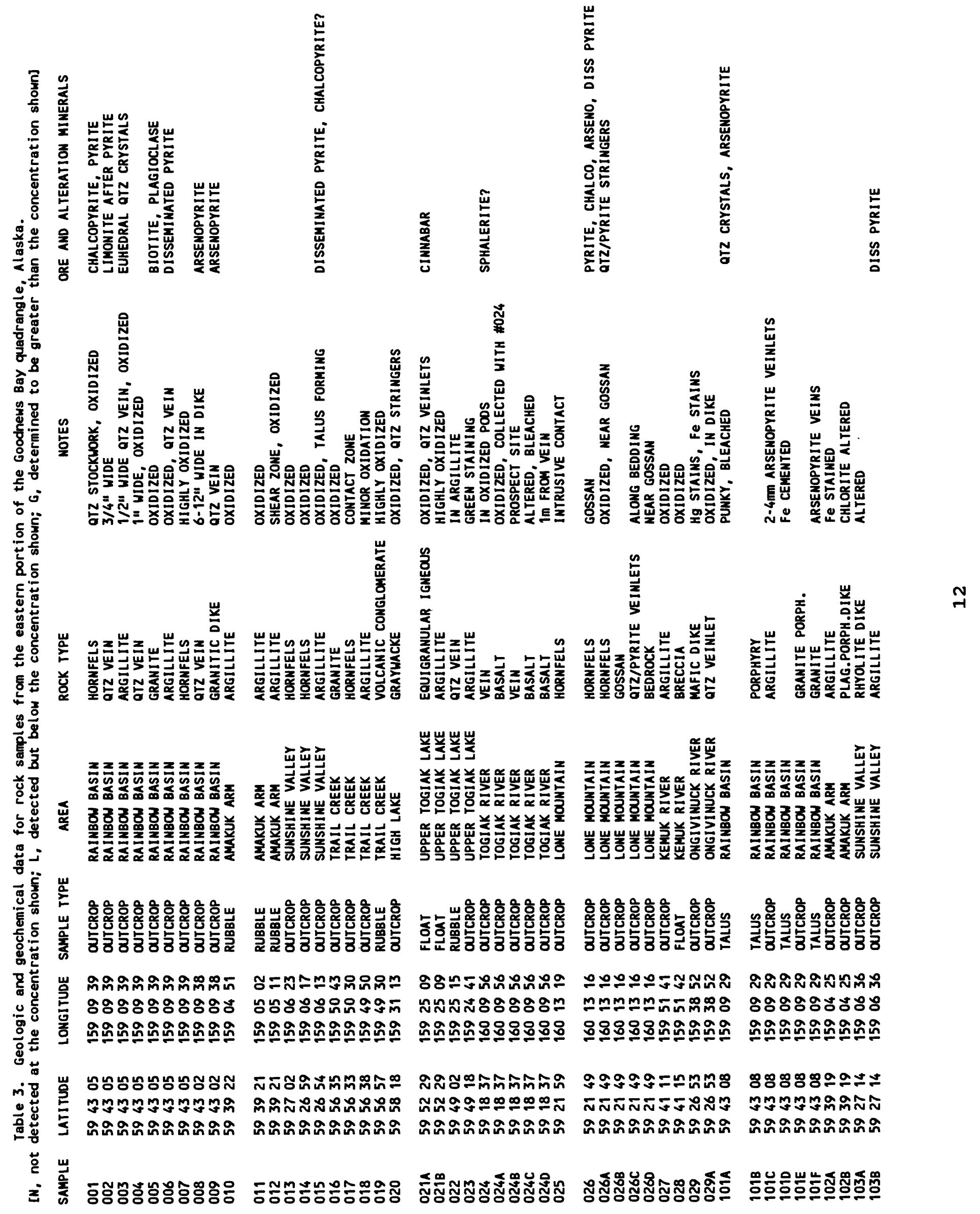




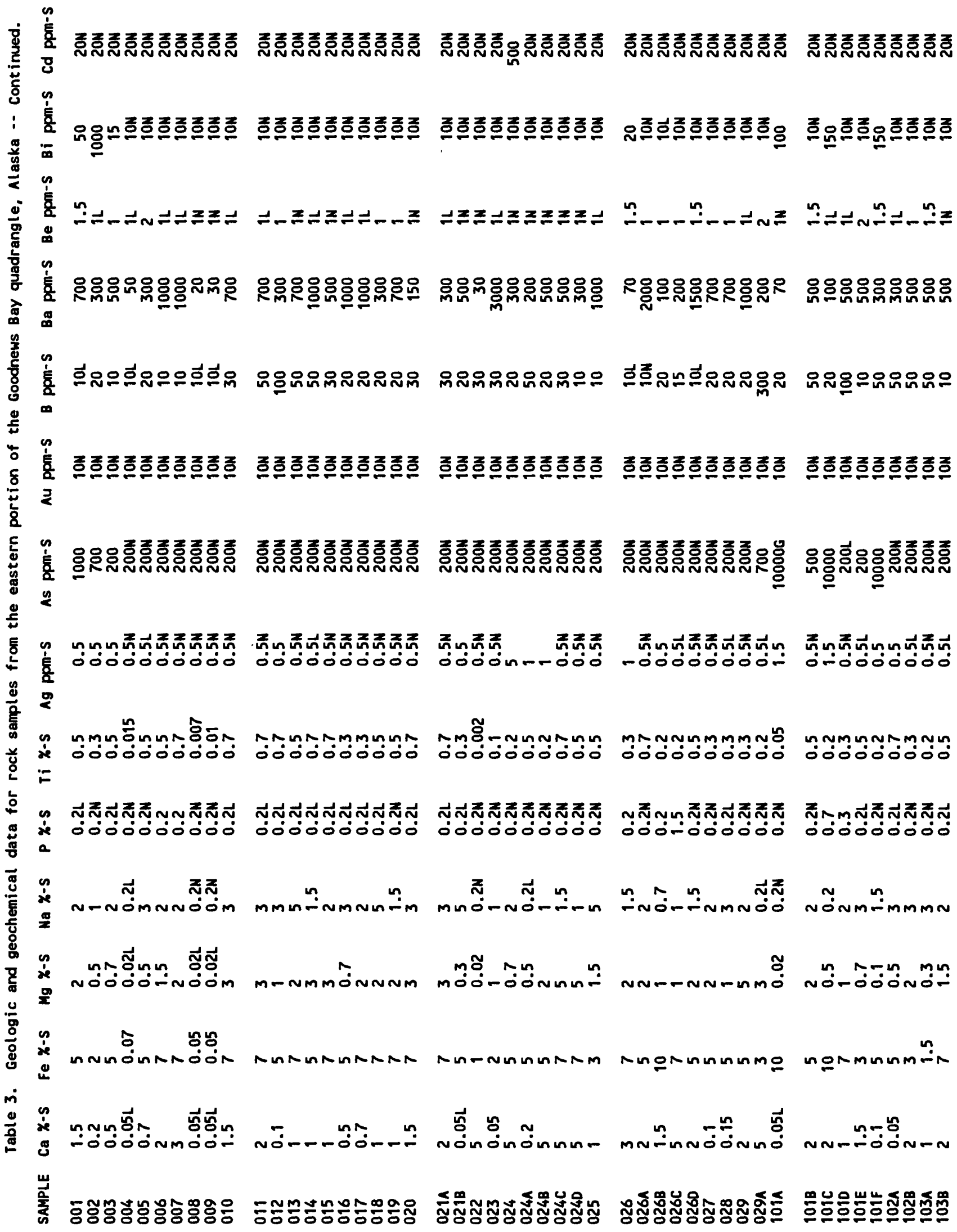




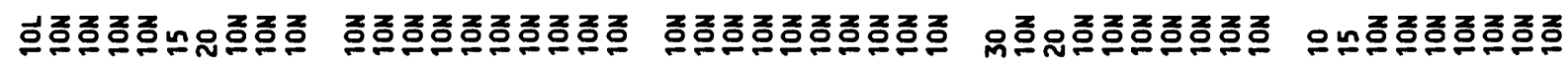

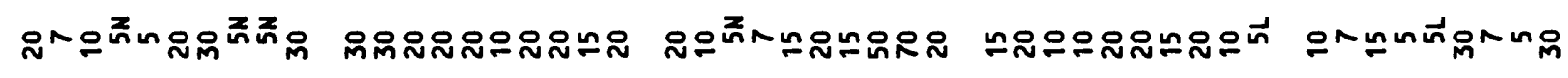

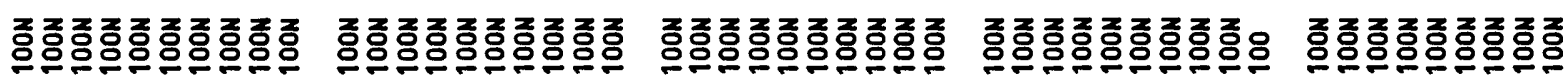

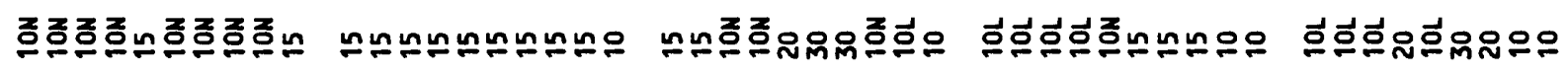

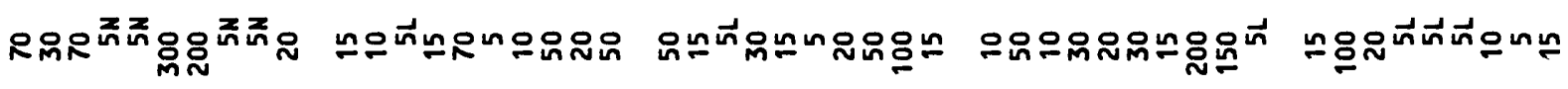

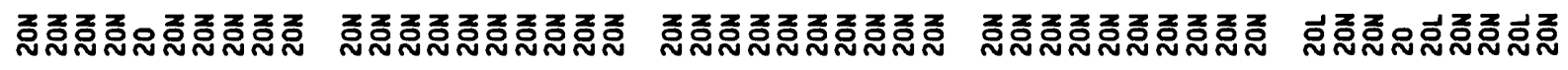

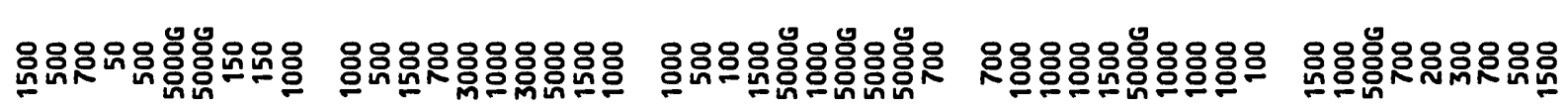

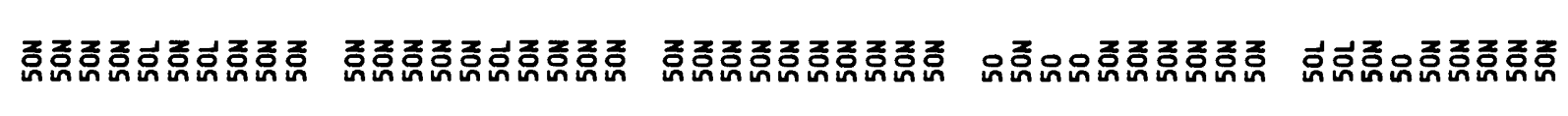

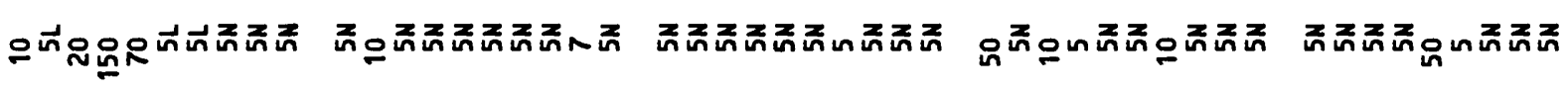

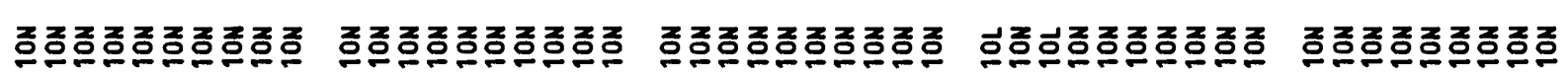
:

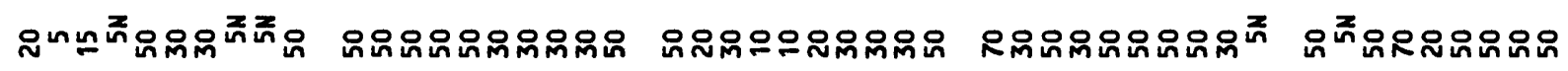

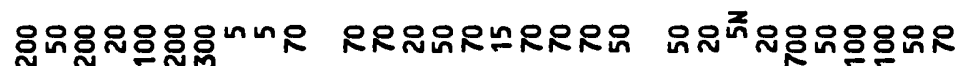

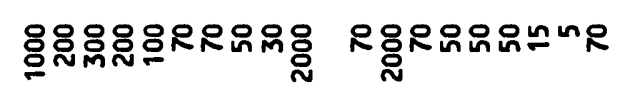

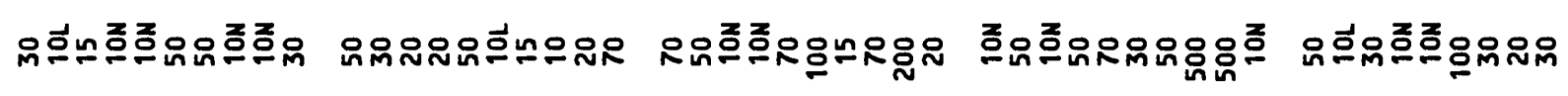

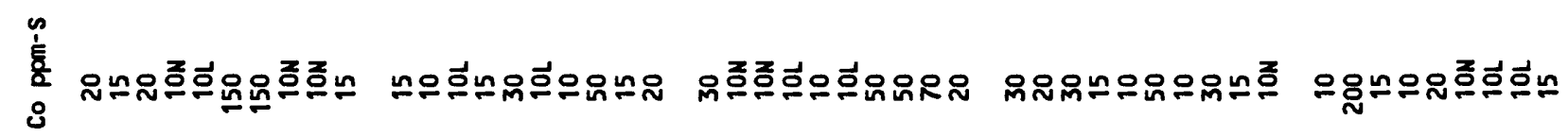

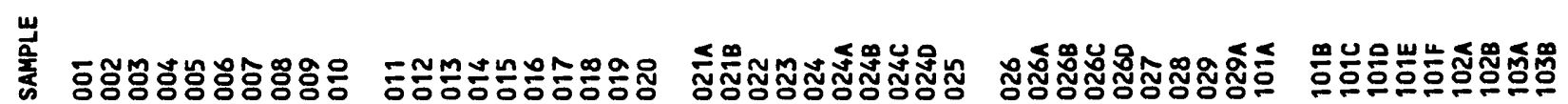


Fg№nnm-00 0000000000

ง ำํำํํำํำำำำ

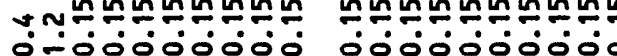
₹

ì

?

高

- - ำ

నุํำ정정정정 000000000

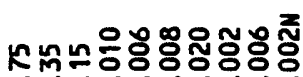

๑-00000000

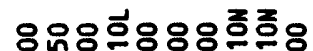

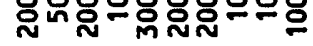

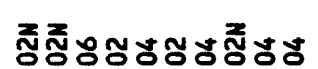
000000000

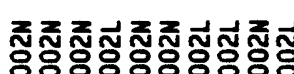
ó00000000

총종응 궁 ㅇํㅇํํำกํํํํํㅇํㅇ 0000000000

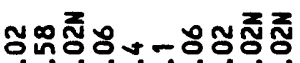
वं00ं00000

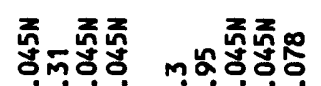
0000mन000

ミミヘミミミミミミー

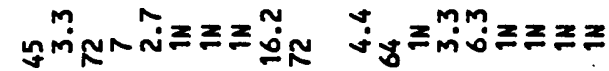

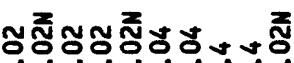

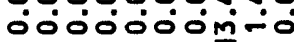

정정정종종 ฐั ¿0000000

\section{증중증증중중증중중형}

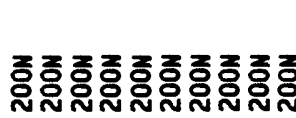

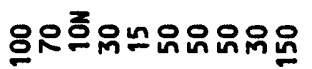

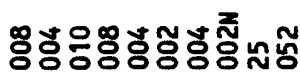
000000000

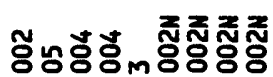
क00000000

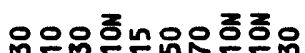

ํํํํํํํํํํํํำ

ำํํํㅎํํํำำำ

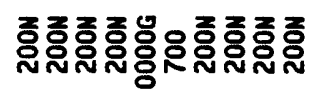

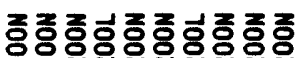

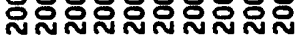

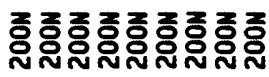

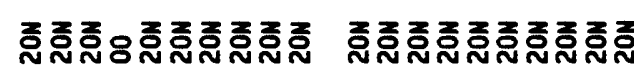

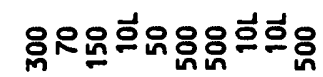

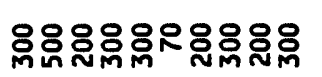

ํํํํㅠ으유융ํํํํํํํ

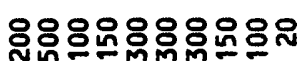

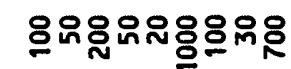

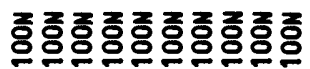

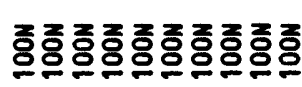

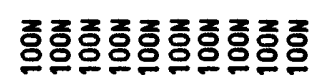

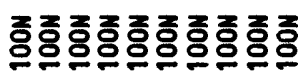

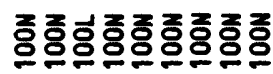

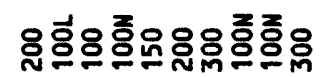

웅휴ํํํㅇㅇํํํํํํำ

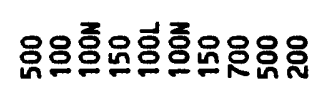

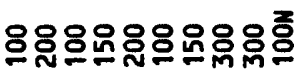

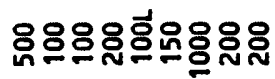

ธำษ

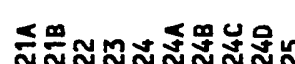

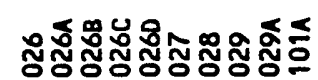

응응응뜨응조웡요용 
的竞 言

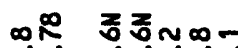

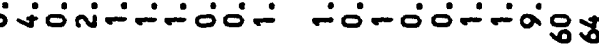

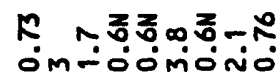

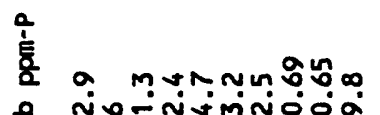

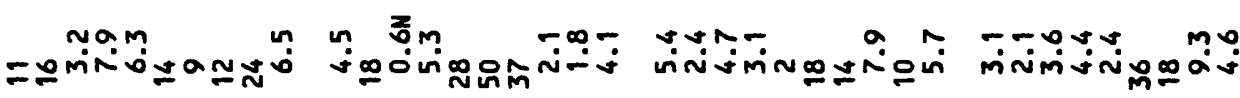

言 울

Tim

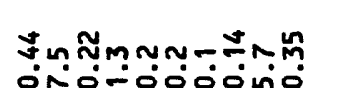

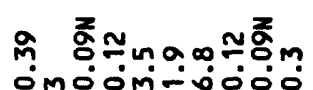

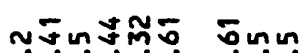

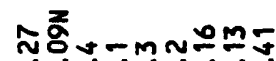

产

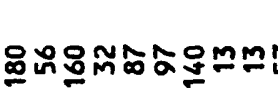

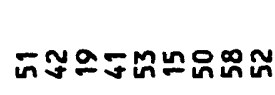

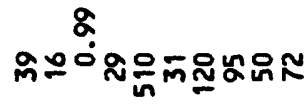

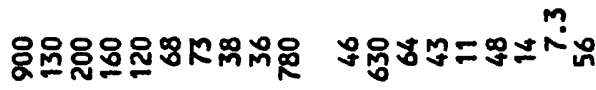

官

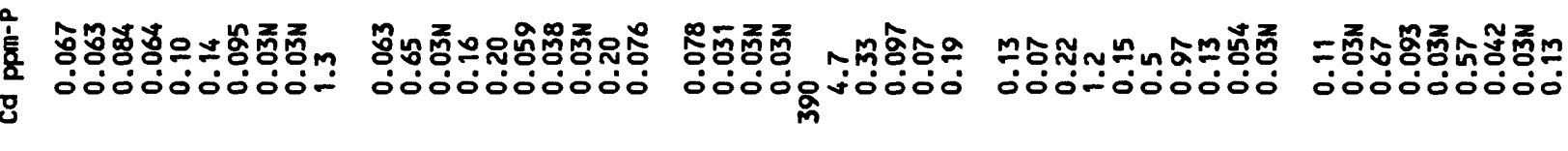

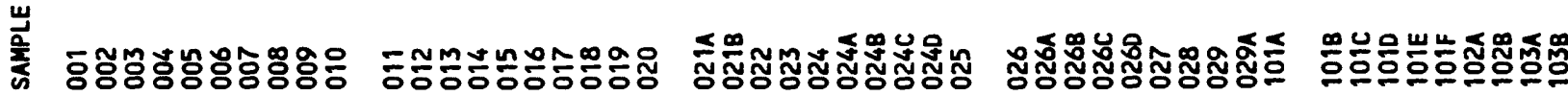




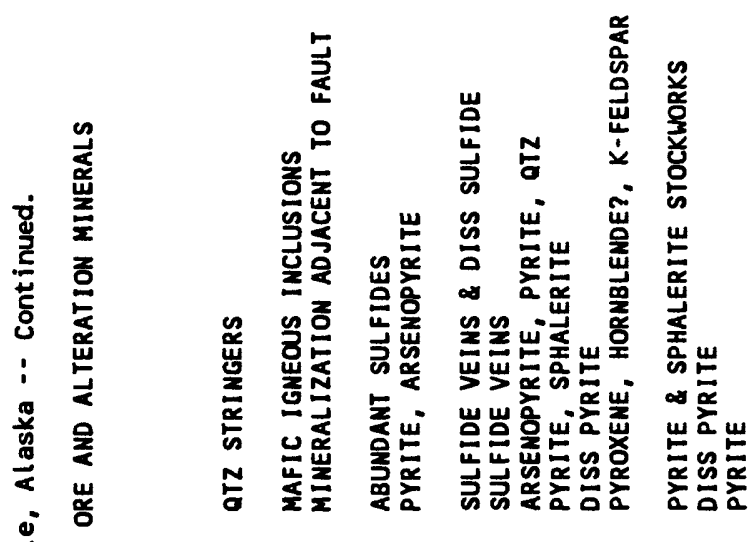

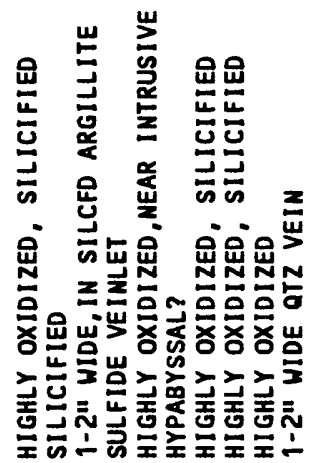

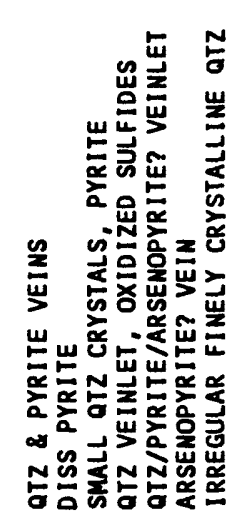

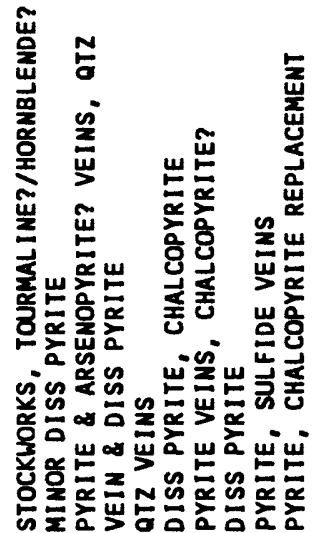

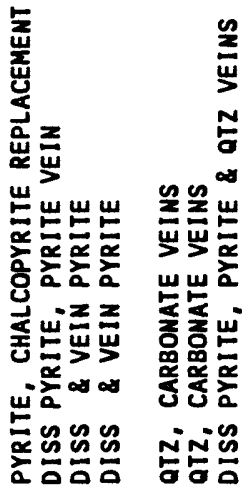

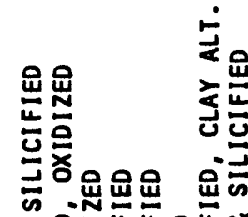

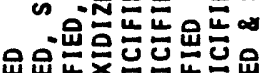

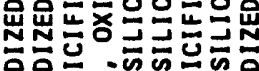

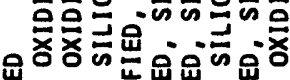

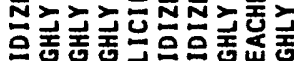

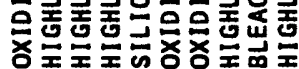
$\bar{a}$

\section{政}

ge

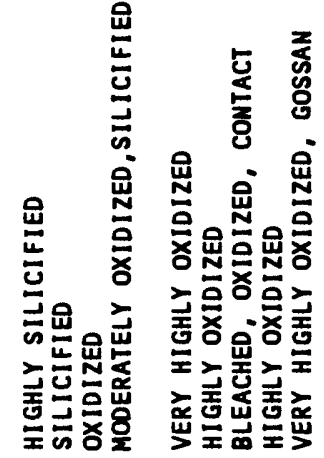

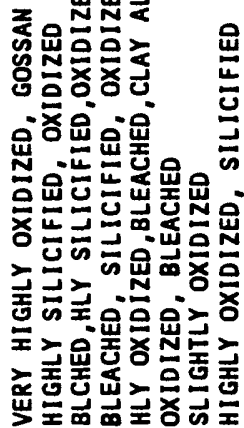

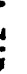

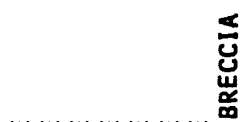

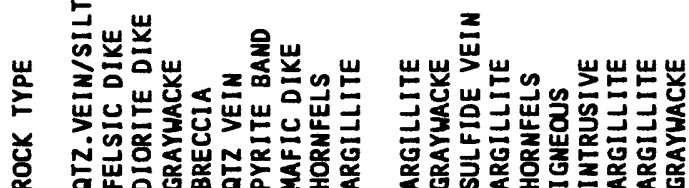

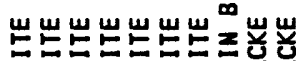

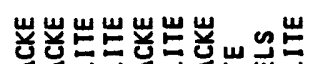

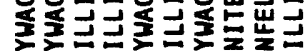

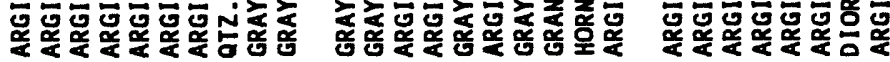

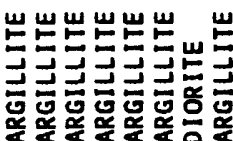

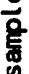

压苕

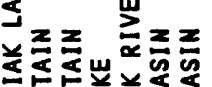

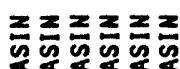

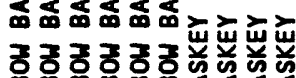

шщ山 ш 응

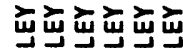

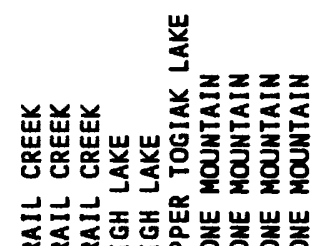

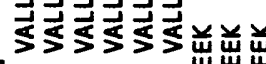

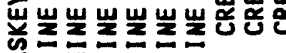

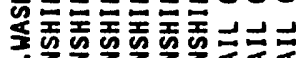

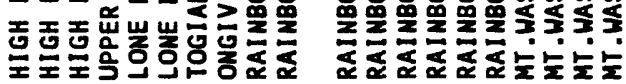

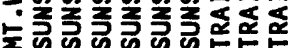

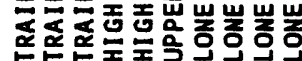

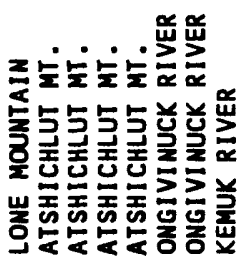

뜬

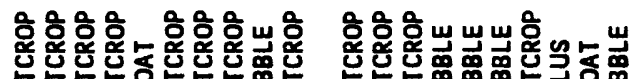

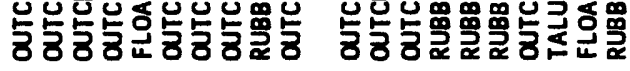

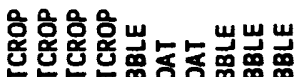

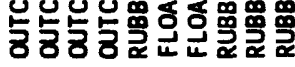

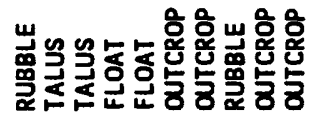

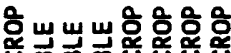

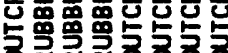

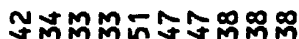

ต๊నిన⿻ำ

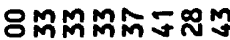

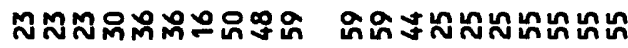

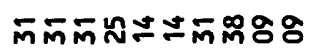

영영영영원ニป

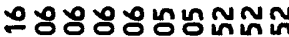

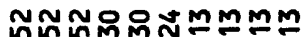

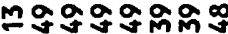

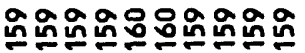

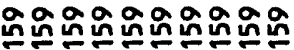

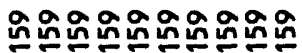

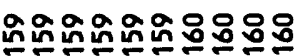

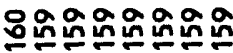

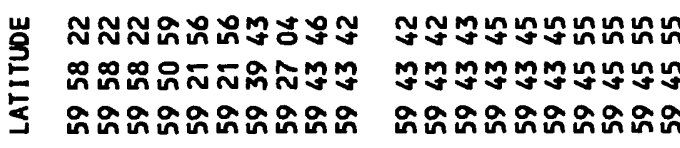

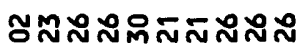

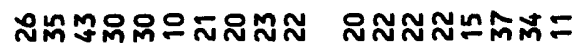

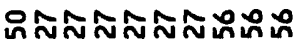

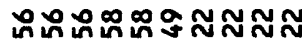

กระ์ธลักษ

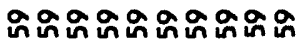

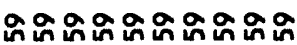

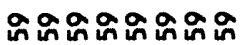

状

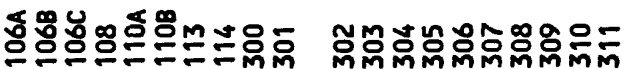

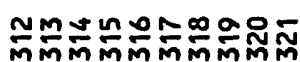

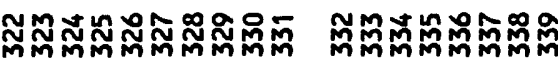




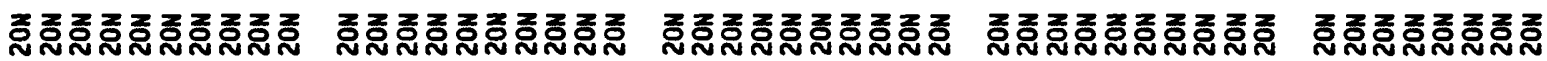

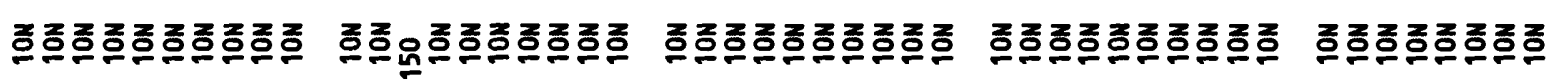

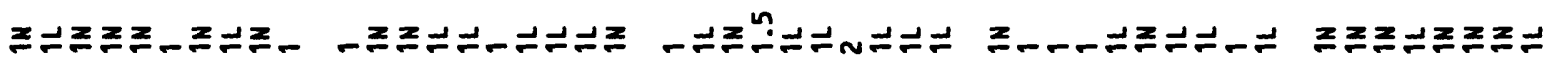

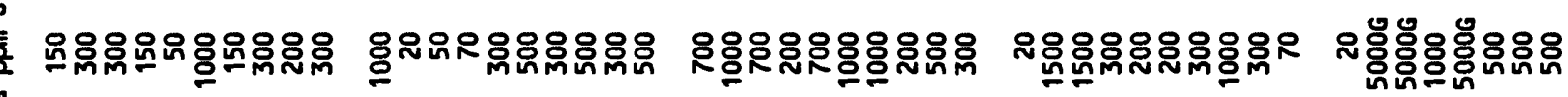

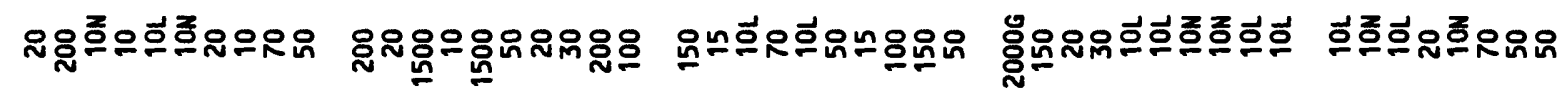

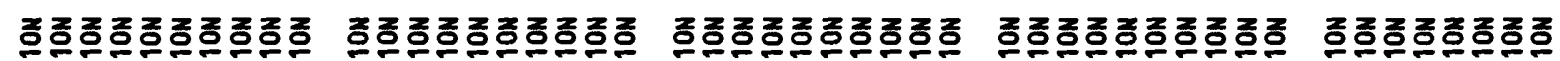$$
\text { (a) }
$$

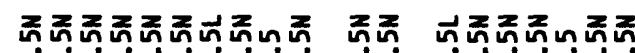
0000000000

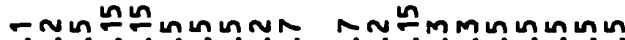

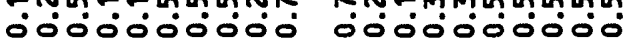

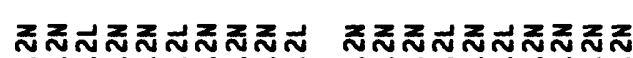
0ं00000000 0000000000

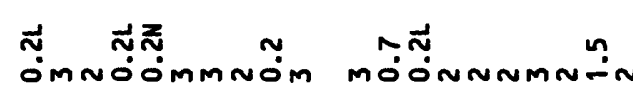

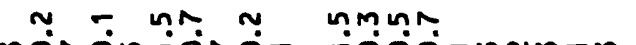

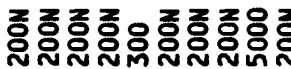

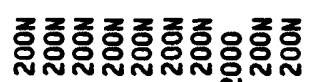

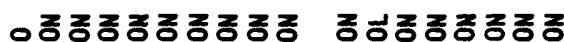
马ำ

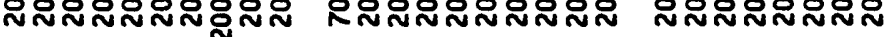

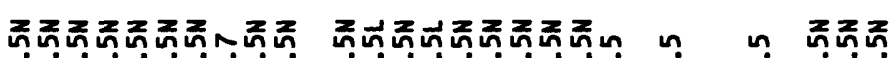

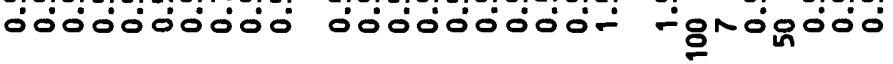

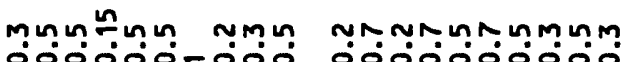
nminnm-mu

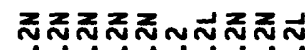
Оं000000000

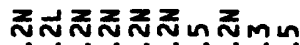

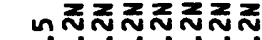

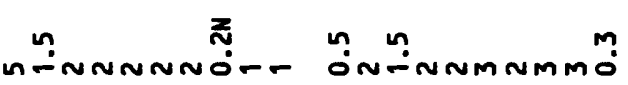
งัก สี่ ก กุต

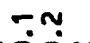

ก. 000-00nm m ำ

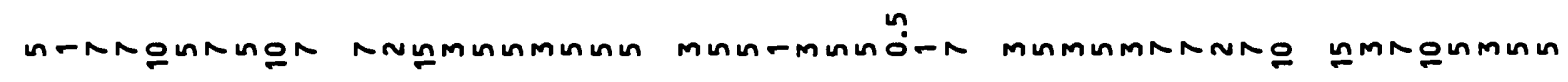

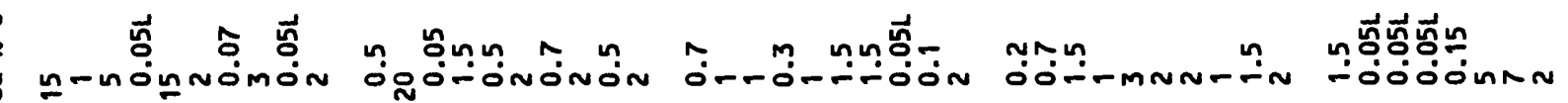

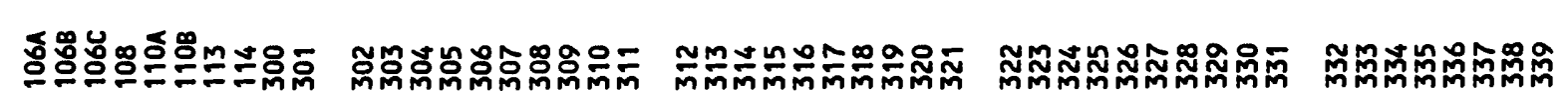




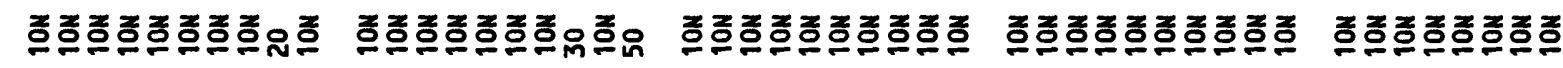

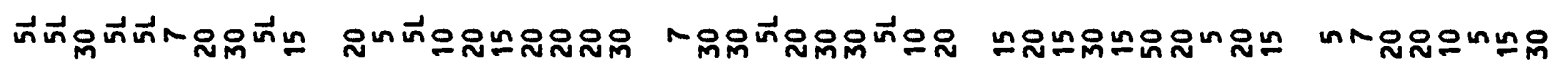

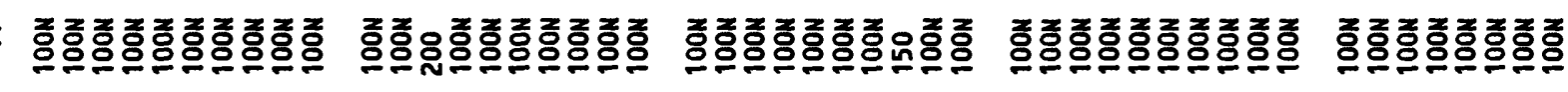

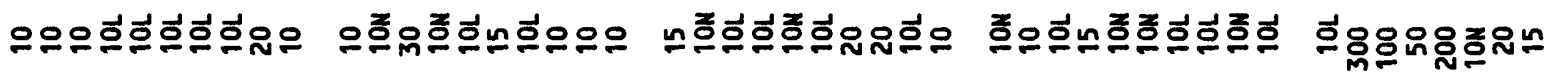
n

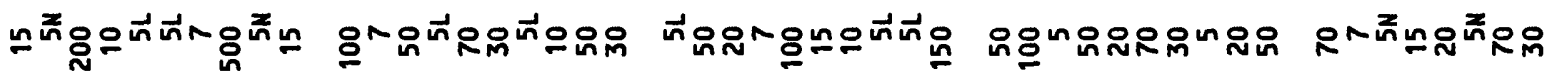
它

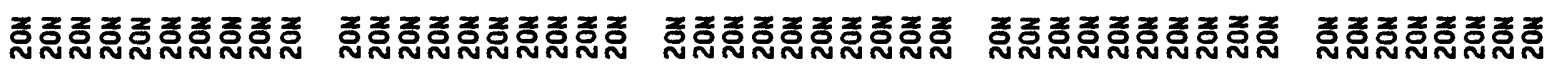

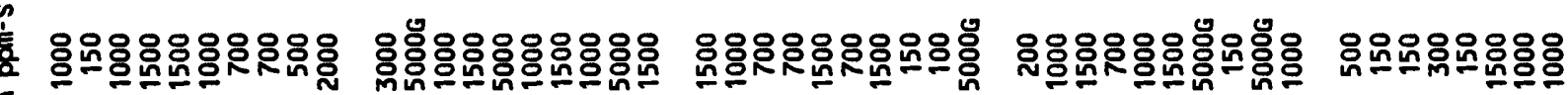
돌

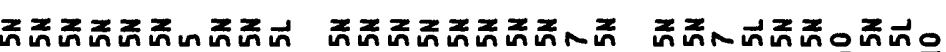

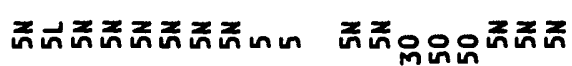
울

晏

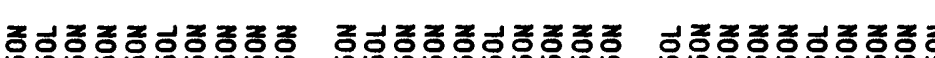

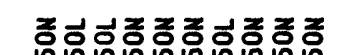

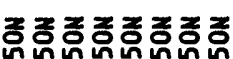

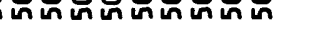

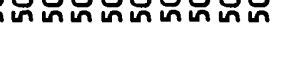

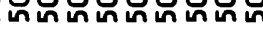

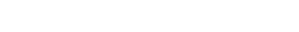

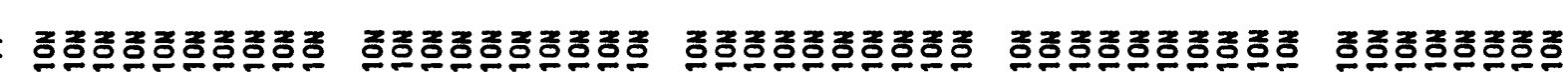
$\stackrel{5}{\circ}$

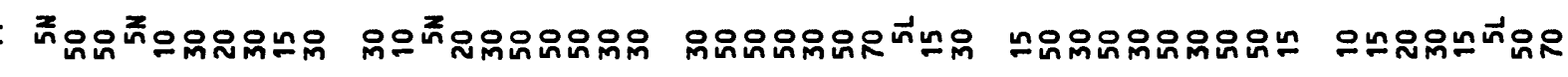

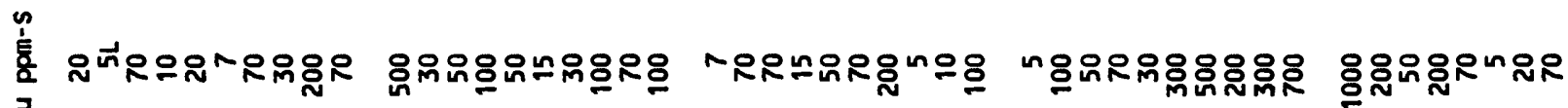
उ

$\dot{\mathbf{E}}$

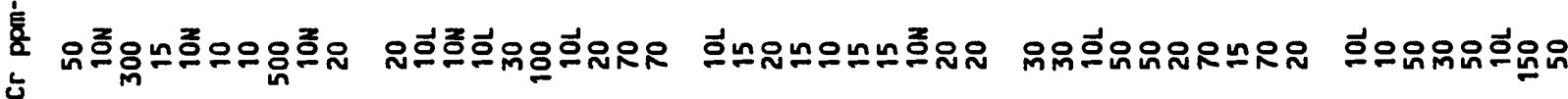
in

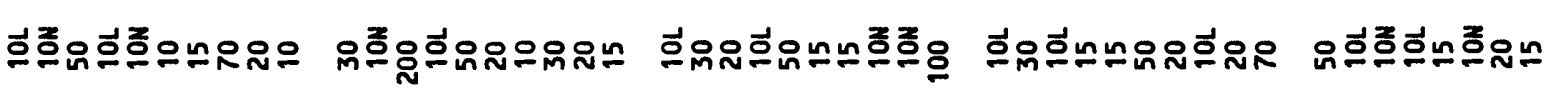




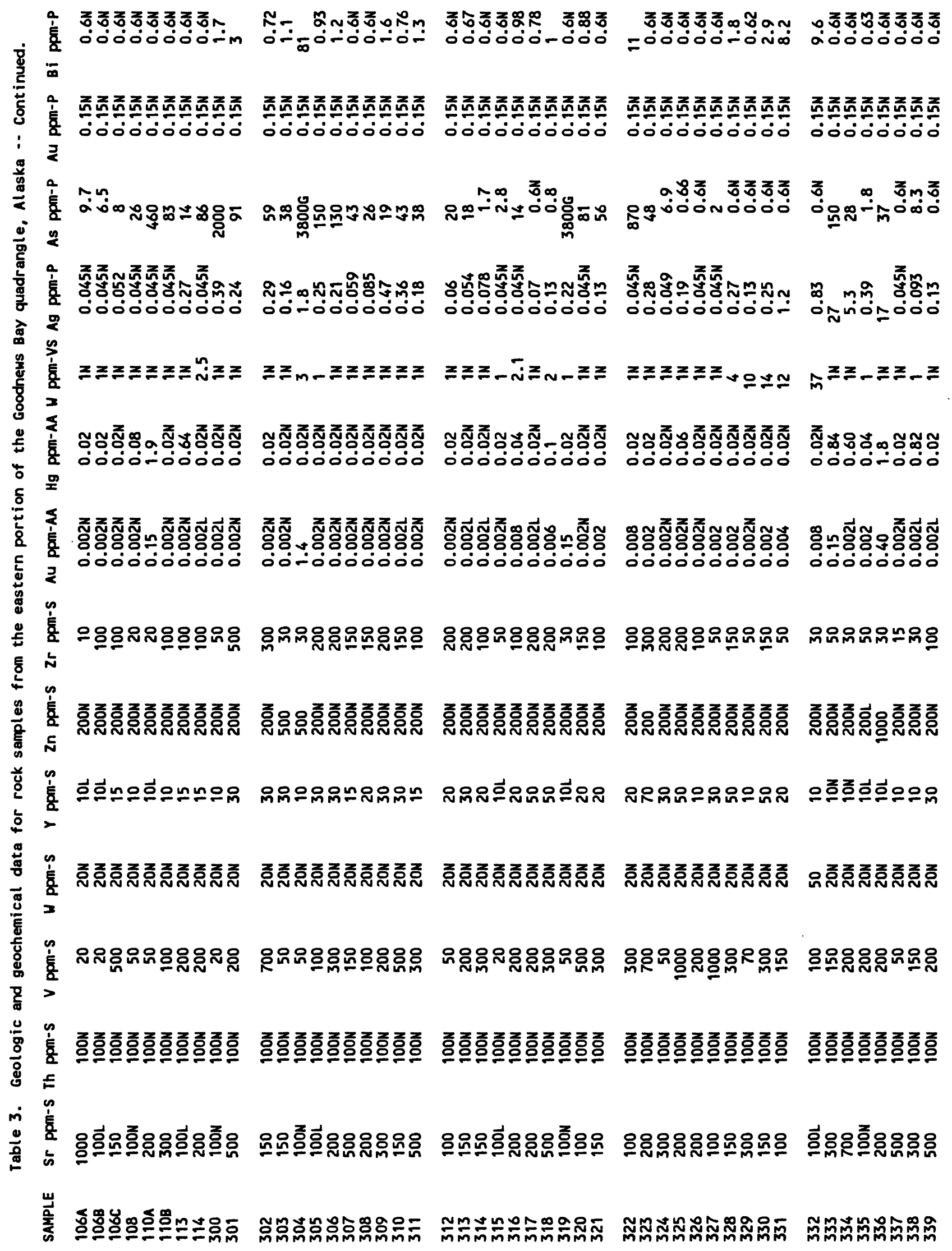




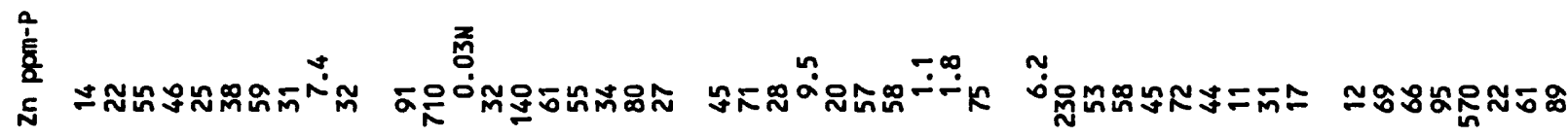

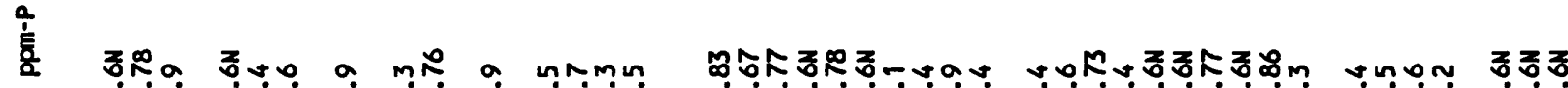

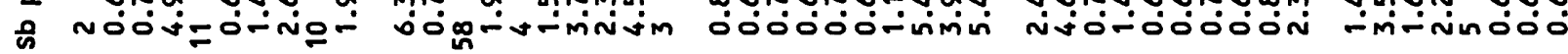

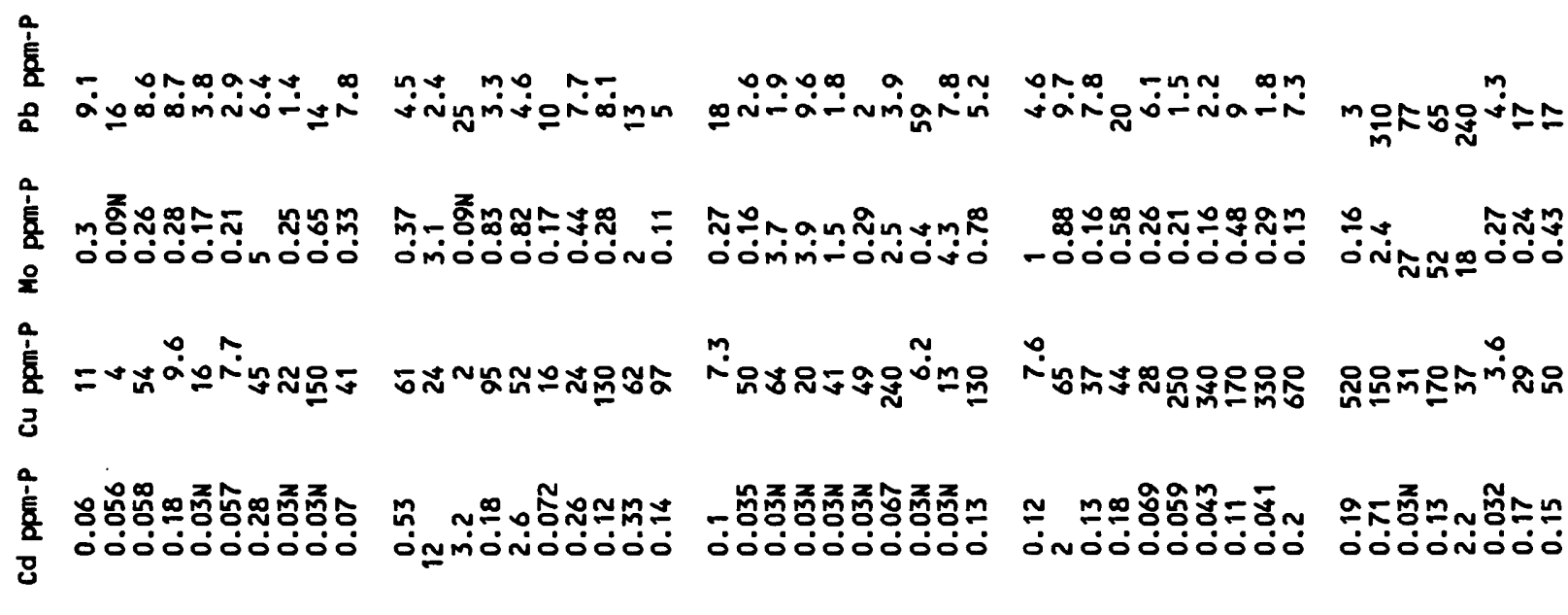

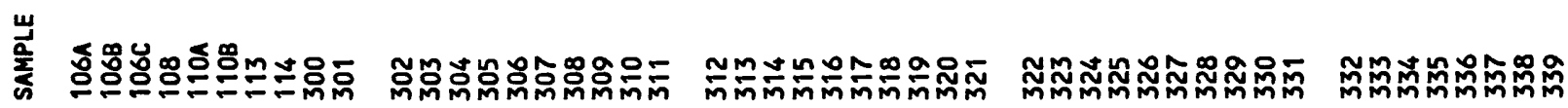

